\title{
REGINA WATERFOWL PARK NESTING SURVEY — 1975
}

ROBYN DONISON, 154 Millar Crescent, Regina, Sask., S4S 1N4

In April, 1975, Mr. Fred Bard, former Director of the Saskatchewan Museum of Natural History, in Regina, encouraged Dwayne Harty and myself to carry out a marsh survey of the Regina Waterfowl Park. In the larger parts of the area, where extra help would be needed Keith Neufeld consented to help us out.

The area surveyed (see map) was from the Broad Street Bridge, following Wascana Lake, east of the Bypass to about one-fifth of a mile east of the Rainbow Bridge. Because of the large number of songbirds that also nest in the area, we felt the birds of the adjoining park areas, (including nurseries and a small area of native grassland) should be surveyed along with the nesting water-birds that would be concentrated along the shore of Wascana Lake and Creek.

The object of the survey was to have accurate up-to-date records on the nesting species of the area to make more complete information available about the birds described in Belcher's "Birds of Regina". Within 20 years most of the birds that are listed in this survey may have vanished because of future plans for park development and the growth of the city.

Most people do not realize the value and uniqueness of the Regina Waterfowl Park. They will refer to it as a waste of money or a breeding place for mosquitoes. Almost 100 of Saskatchewan's 326 species of birds nest in this area. If it is destroyed, as so many other marshes have been across the country, most of these species will begin to disappear. They will not, as most people think, find another nesting area, they will simply vanish.

The last time a survey of this type was done in the area was in 1962 when Richard Sanderson and Bill Fleming, with the guidance of Fred Bard, surveyed the same area. (Blue Jay, March, 1964).

Weather Summary: Normals based on records from 1941-1970.

With the aid of the monthly meteorological bulletins published by the Regina Weather Office, Atmospheric Environment Service, a summary of weather conditions from April to June is presented below.

$\begin{array}{llll} & \text { April } & \text { May } & \text { June } \\ \text { Mean Temperature, } 1975 & -0.1^{\circ} \mathrm{C} & +10.6^{\circ} \mathrm{C} & +15.5^{\circ} \mathrm{C} \\ \text { Normal Temperature } & +3.3^{\circ} \mathrm{C} & +10.6^{\circ} \mathrm{C} & +15.3^{\circ} \mathrm{C} \\ \text { Mean Windspeed, } 1975 & 13.3 \mathrm{mph} & 12.1 \mathrm{mph} & 9.6 \mathrm{mph} \\ \text { Normal Windspeed } & 14.3 \mathrm{mph} & 14.5 \mathrm{mph} & 13.3 \mathrm{mph} \\ \text { Mean Rainfall, 1975 } & 1.12^{\prime \prime} & 0.6^{\prime \prime} & 7.84^{\prime \prime} \\ \text { Normal Rainfall } & 1.43^{\prime \prime} & 1.5^{\prime \prime} & 3.24^{\prime \prime} \\ \text { Mean Snowfall, 1975 } & 7.5^{\prime \prime} & & \\ \text { Normal Snowfall } & 4.1^{\prime \prime} & & \end{array}$



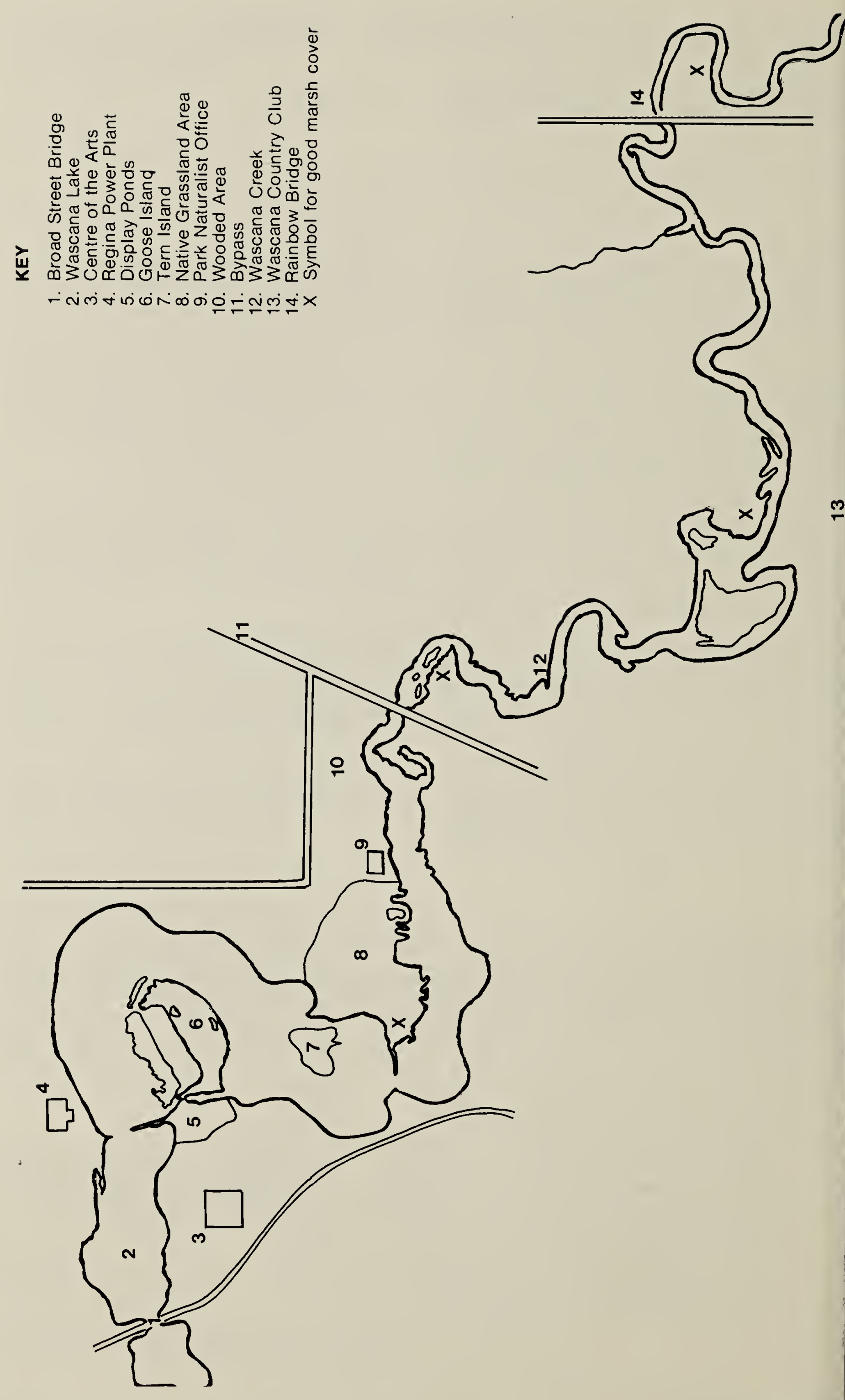
A storm front in northern Nebraska, in mid-April, held the majority of our waterfowl in the States, with our earliest ducks arriving as late as the tenth of April.

Regina's weather during April was cold, with heavy snow during the first two weeks and then warming up to near normal conditions. May was cool for the first couple of days, but throughout the rest of the month it continued to get milder with fairly light winds and little rainfall. June weather varied throughout the month with light winds and very heavy rainfall in late June. On June 25 there was record rainfall in 24 hours, 5.22 inches fell over the city, with strong southeast winds (30-45 mph) and tornados were observed north of the city. Rain continued into the 26 and the evening of the 27.

June had the highest recorded rainfall - 7.84 inches - in almost 90 years of records. This did some, but surprisingly, not much, damage to the breeding bird population and, while most of Regina's 150,000 people were busily bailing water out of their homes, I was busily building up the two dozen, near flooded, tern nests on Tern Island!

The water levels for 1975 were very high, almost as high as 1974. Most of Goose and Tern Islands were under water during late April and early May. The water level throughout the rest of the spring and summer dropped fairly quickly, even after the heavy June rains.

Probably the best nesting sites in the area are Goose and Tern Island, bypass, Rainbow Bridge and the native grassland areas. Tern Island alone boasts a number of birds breeding on and around it, with a total of 119 nests and 353 eggs found.

The best area for songbirds is the shrubbery around the native grassland along with the wooded area to the west of the bypass. The best area for divers is east of the bypass, although some breed around Tern Island and the native grassland areas.

\section{Annotated List of Species}

$\mathrm{n}$ - nest, e - eggs, y - young

Horned Grebe: Rare but regular. 2n, 11e. Probably only 2 or 3 pair nest within the area each year. Both nests found near Rainbow Bridge on June 7.

Eared Grebe: Fairly common. 7n, 42e. Five nests in one colony found off the north shore of the creeks opposite the Wascana Country Club. Two nests were found close to the shoreline of the native grassland area. A large colony was present in the marsh, at the Regina Power Plant, up to 1973 where 35 nests were located, but in 1974 only two nests were found.

Pied-billed Grebe: Uncommon. 3n, 18e. Uusally Pied-bills are fairly common. 6 or 7 pair nesting in the area each year. Throughout July young were seen.

American Bittern: Rare but regular. $4 y$. An adult bird was flushed from reeds at the Rainbow Bridge on August 9. Four young, barely old enough to fly, flew out behind adult bird. Adult birds flushed through May, June and July along the shoreline of the native grassland areas and at Rainbow Bridge, but no other nests or young were found. Probably 1 to 3 pairs of bitterns nest in the area each year. (One nest found at Rainbow Bridge in June, 1973).

Canada Goose: Abundant. About 135 nests counted. Over 1,000 eggs were laid, but apparently only a little over half were hatched. One nest contained 14 eggs, one contained 15. Flightless young seen throughout the area until September 10. Adults started laying eggs in early April (usually late March). Higher water levels this year flooded many nests. In 1974 10\% more nests were flooded than in 1975 . 
sod

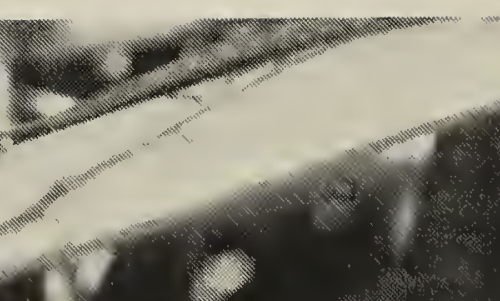

(1) $-5, \% 5$

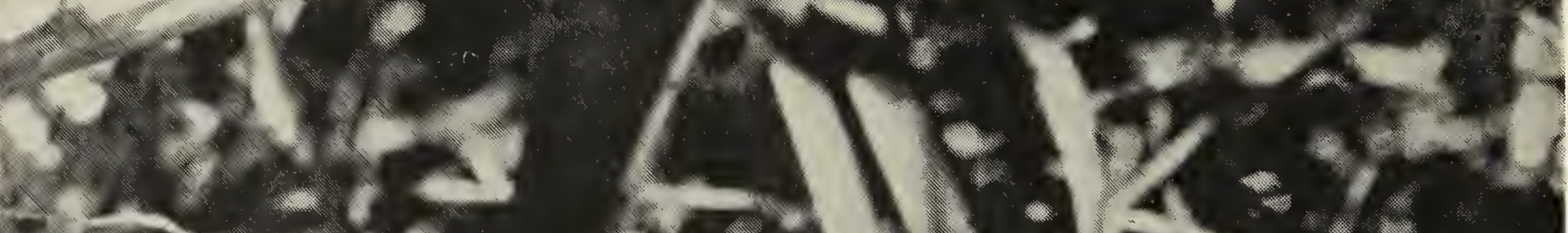

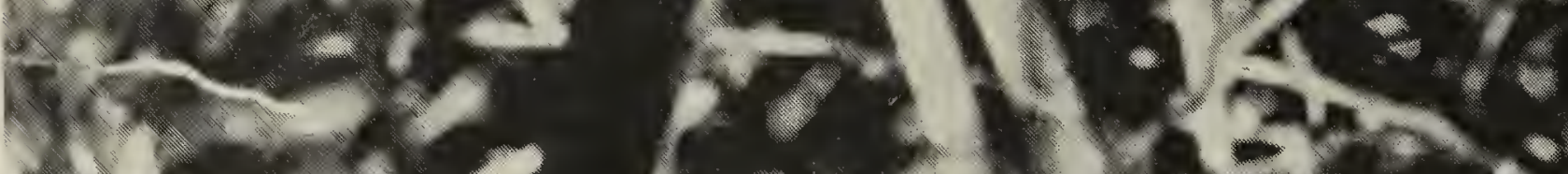

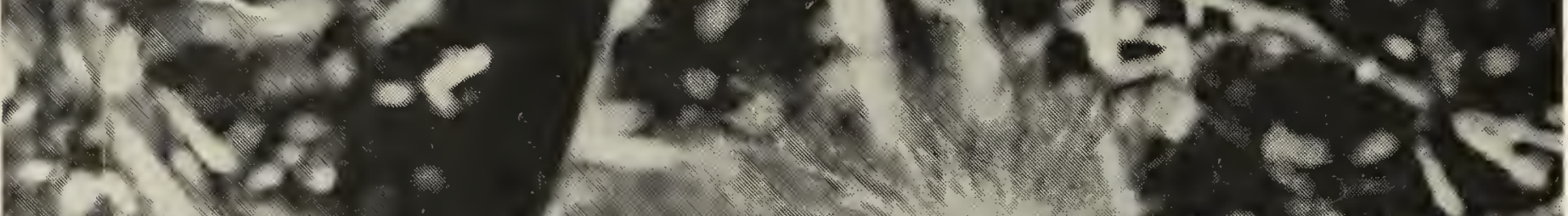
ac.

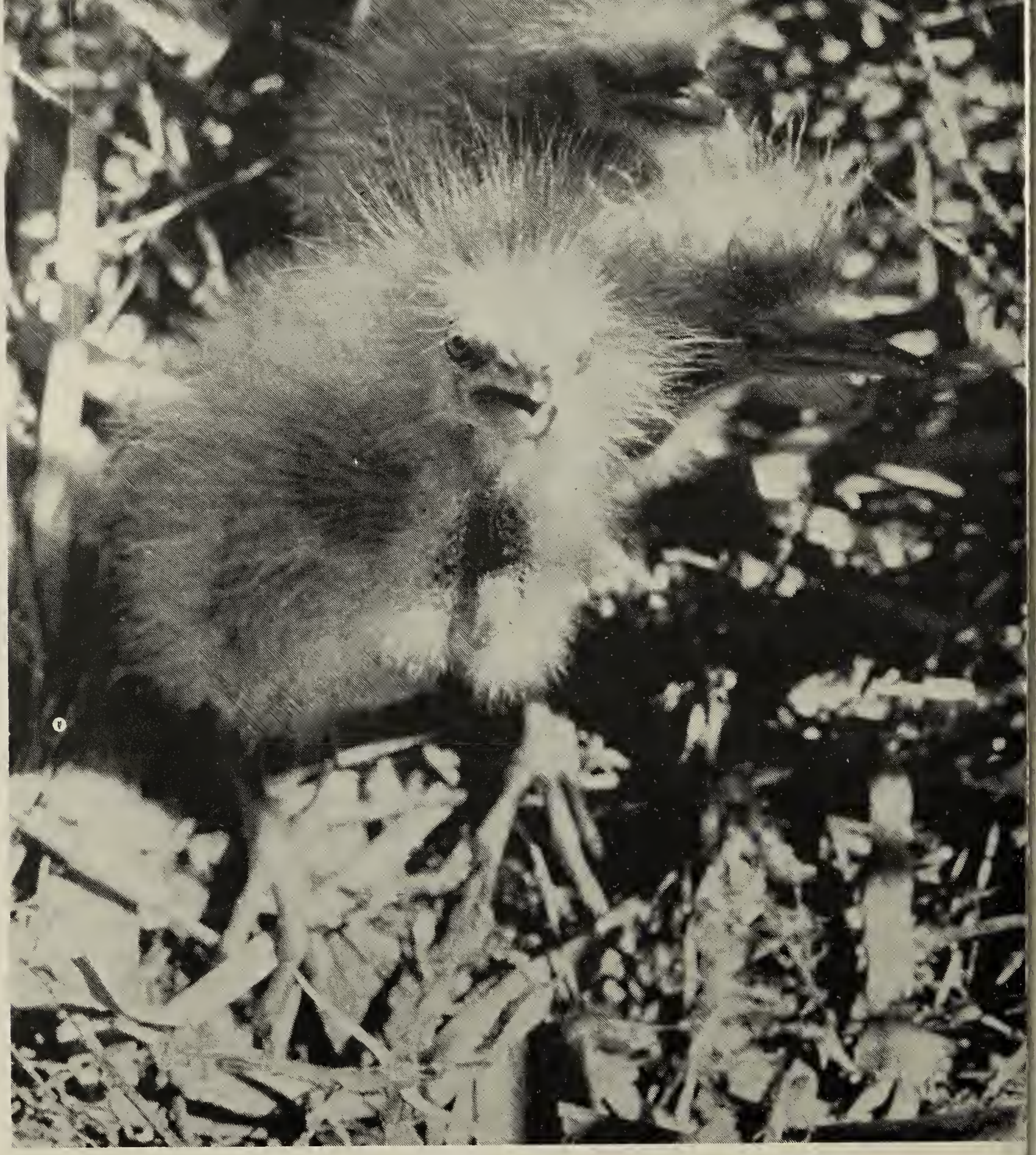


Mallard: Very common. $21 \mathrm{n}, 154 \mathrm{e}$. Nests were found as early as the fourth week of April. Fred Lahrman and Lorne Scott reported finding two nests in old crow nests, which were 20 yards apart and 12 feet up in spruce trees. On a survey of the young ducks on July 27,21 young were counted on the lake, from the bypass, west to the Display Ponds. One nest was found the 3 rd week of July and flightless young were seen from early June to October. Three nests were found on Tern Island.

Gadwall: Common. Although only 5 nests and 27 eggs were found, adults with young were seen throughout the area from June to October. On July 27, 33 young were counted. A slightly above average nesting year for Gadwall.

Pintail: Common. 6n, 56e. Pintails were nesting as early as April 25 and young were still flightless in October. A female Pintail was observed incubating 5 Canada Goose eggs during July and part of August. Her original nest which was 3 feet from the goose nest was destroyed by intruders and she started to sit on the nearby, recently abandoned, goose nest. She plucked down from her breast and lined the nest with it, until she was forced, by time, to desert the goose nest. On July 27, 22 young Pintails were counted in the area.

American Wigeon: Common. 6n, 48e. A slightly above average nesting year for Wigeon. Not many nests were found, but adults with young were seen all over the area. Flightless young were seen into October. On July 27, 28 young were counted.

Green-winged Teal: Rare but fairly regular. In, 9e. Only one nest found, but, 2 broods of young seen during summer. The nest was found on Goose Island in mid-July.

Blue-winged Teal: Common. 7n, 74e. About as common as Pintail. The first nest was found in early June. Flightless young were seen until the end of September. On July 27, 25 young were seen.
Shoveler: Common. 5n, 46e. Not many nests were found, but, like other puddle ducks, adults with young were seen commonly over lake until October. 23 young were counted on July 27.

Redhead: Uncommon. 3n, 38e. One nest was found on Tern Island and the other 2 were found near the Rainbow Bridge. Usually 2 to 4 pairs nest in the marsh each year. On July 26, 14 young were counted.

Canvasback: Fairly common. 4n, 33e. Two nests were found near Tern Island, the other 2 were found near the Rainbow Bridge (near Redhead nests). Three to 5 pair usually nest in the marsh each year. On July 27,15 young were counted.

Lesser Scaup: Rare but regular. 1n, 9e. The nest was found near Tern Island. A few weeks later a female with 5 young was seen. That same day, at the Rainbow Bridge, another 6 young were seen with a female. One to 2 pairs probably nest in the marsh each year, with additional nests when water levels are more favorable. On July 26. 11 young were counted.

Ruddy Duck: Uncommon. 2n, 22e. Three groups of young $(12 y)$ were seen on July 26. One nest was found near Tern Island, the other at Rainbow Bridge. Probably between 2 and 5 pairs nest in the marsh each year (depending mainly on water levels).

Gray Partridge: No nest was found, but birds were flushed near the shrubbery at the native grassland area and east of the bypass, throughout the summer. Probably fairly common.

Virginia Rail: Rare but regular. 1n, 9e. Five birds were seen throughout the area during the summer and one broken egg was found along the shore east of Rainbow Bridge. The nest was found opposite the Wascana Country Club. Probably between 2 to 5 pairs nest each year.

Sora Rail: Common. 3n. 24e. Nests found in marsh near the native grassland, Rainbow Bridge and Wascana Country Club areas. About 2 weeks after finding the nests (late June), 7 families of Soras were seen in 


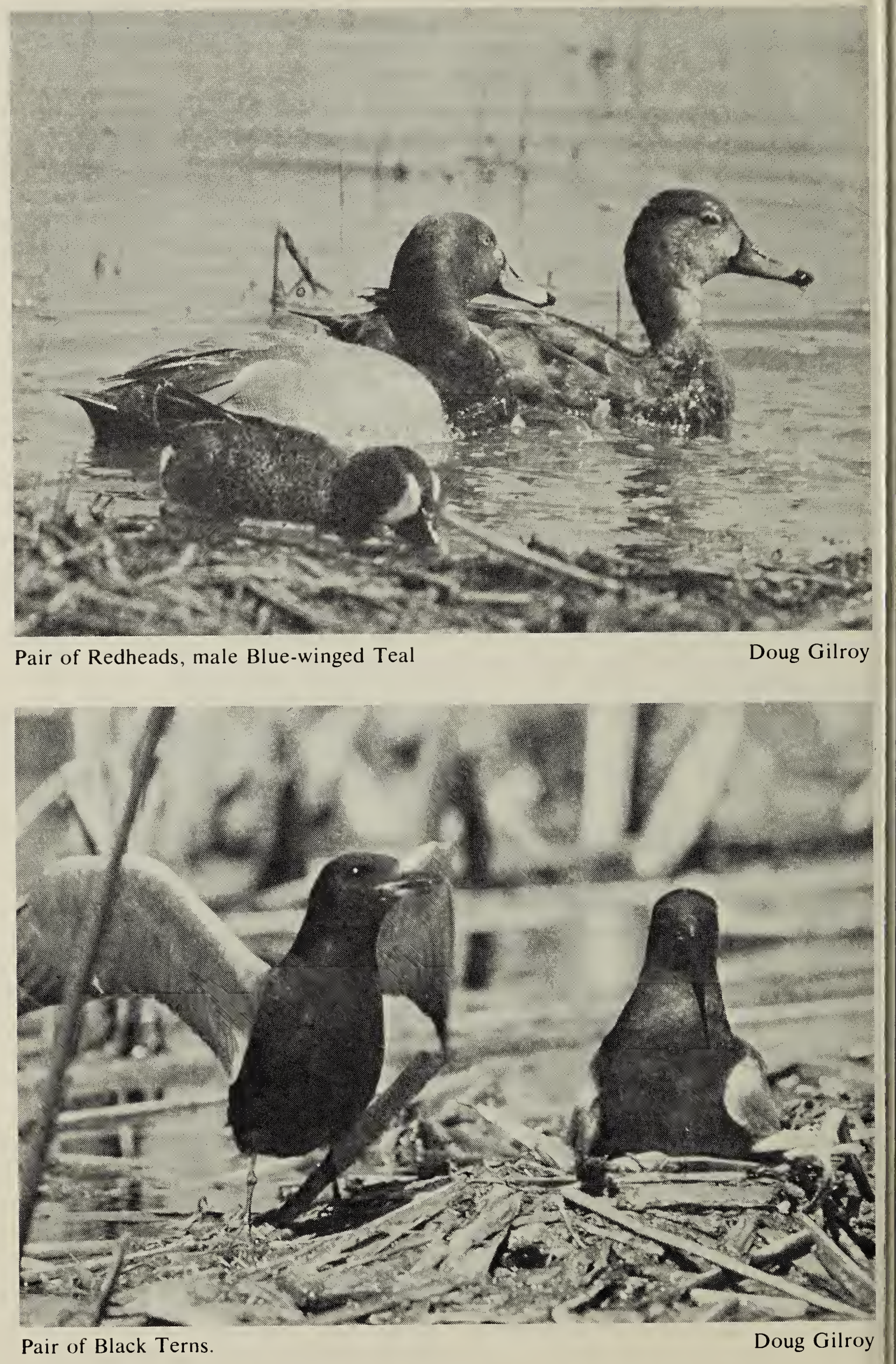

Pair of Black Terns.

Blue Jay 
the area. Two families were seen on Tern Island.

Yellow Rail: No nests or young were found but adult birds were heard throughout late May, June and part of August, near the Wascana Country Club - Rainbow Bridge areas. Mostly in wet, reedy fields.

American Coot: Very Common. 25n, 249 e. Only 9 pair nested west of the bypass. Families of flightless young were seen until October. About an average year for coots, but this year numbers were low compared to the numbers in Sanderson's 1962 Nesting Survey, when 117 nests were found from the Broad Street Bridge east to the Wascana Country Club area. Three coot nests were found on Tern Island compared to 21 in 1962.

Killdeer: Common. 4n, 15e, 12y. Our most common nesting shorebird. Adults on territory throughout area (including Goose and Tern Islands). Nests were found on Tern Island, Regina Power Plant Roof, native grassland and Rainbow Bridge areas.

Common Snipe: Uncommon - status as a resident not clear. No nests or young were found, but, one pair was definitely on territory on the northwest side of Rainbow Bridge, another pair on territory east of Rainbow Bridge. Both were in wet fields.

Spotted Sandpiper: Common. 5n, 24e, $9 y$. This is the most common sandpiper of Wascana. The nests were found on Goose and Tern Islands and at the Regina Power Plant, native grasslands and Rainbow Bridge areas. One bird was still on eggs on August 5. The number of eggs varied from 3 to 5 .

Upland Sandpiper: No nests or young were found but one pair was just outside of the area, east of Rainbow Bridge. They were seemingly on territory during late May, June, July, August and part of September. During late June, July and August the birds flew and dove at me as if protecting young.

Willet: Uncommon but regular. 5y. Formerly bred throughout most of the area in stubble fields. Presently only nest from Wascana Country Club east.
No nests were found, but two groups of young were observed about one-fifth of a mile apart in the stubble field north of the Wascana Country Club. In one family, two young were found; in the other, three young. Apparently it occasionally tries to breed west of the bypass on Goose Island, in the native grassland or bypass areas; one pair was observed on territory on Goose Island during May until mid-June. Unfortunately, their nesting territory was the chosen site of a photographer, who was photographing the nesting Canada Geese. The Willets were forced to leave Goose Island to find another place to nest. Probably 2 or 3 pairs nest in the area each year.

Marbled Godwit: Rare but regular. No nests or young were found, but one pair was on the territory east of Rainbow Bridge during most of the summer. Probably between one and two pair nest in the area each year.

American Avocet: Uncommon but regular. 2n, 7e. Both nests were found near Rainbow Bridge. Like the Willet and Godwit, the Avocet formerly nested west of the bypass, it now rarely does. Usually around three pair nest in the area each year.

Wilson's Phalarope: Fairly Common. In, 3e, 4y. Nests from Wascana Country Club east. Also, occasionally breeds west of bypass. One nest was found in the field on the northwest side of Rainbow Bridge. The same day, two other families of young were seen in the same area. In one family, one young was found, in the other, two young. In total about 5 pair nested in the area. Both sexes defended nests and young throughout the summer. Probably between three and seven pair nest each year.

Forster's Tern: Rare. 4n, 13e. Two pairs were found nesting in the Tern Island area among the cattails. Forster's Terns are separated from the nearby Common Terns by the call and the nesting site. Two other nests were found near the Rainbow Bridge in the Black Tern colony. According to Belcher, the Forster's Tern has bred only once before in the area (June 1960). 
Common Tern: Very common in their limited nesting habitat (Tern Island). $73 \mathrm{n}, 179 \mathrm{e}$. Tern Island is the only area in or around Regina that Common Terns nest. These birds are now faced with the problem of the city moving in on their single nesting site and forcing the birds out of the bird sanctuary. So far there are no signs of the number of the terns decreasing. The island was built up a few years ago so that flooding would not be as much of a threat to the terns. This year was an excellent nesting year for them. The regular number of nesting pairs is usually 25 to 30 . Terns started nesting in late May and a few were on eggs in mid-July. On June 25, 26 and 27, extremely heavy rains caused the lake to rise a few feet and 10 percent of the nests were destroyed; 9 percent of the pairs renested. Strict protection and continued preservation of the area may help save these remarkable birds from leaving the marsh. Already the numbers of the Common Terns are decreasing across their central and eastern North American breeding range.

Black Tern: Uncommon. 5n, 14e. Not quite as common as usual (10 to 25 pairs). Nests found east of Rainbow Bridge. Sometimes the nests were west of the bypass, around the Tern Island area.

Rock Dove: Fairly common. No nests or young were found but up to 50 pairs nest in the area. About 35 of these nest at the Regina Power Plant.

Mourning Dove: Very common. 37n, 69 e. Probably as common in the area as they ever were. Some of these birds raise 3 broods a season. Four nests were found on the ground. One nest was found built onto a bunch of cattails. Birds were on eggs in midAugust. They favored shrubbery around the native grassland area. Two nested on Tern Island.

Black-billed Cuckoo: Uncommon but fairly regular. $3 \mathrm{n}, 8 \mathrm{e}$. Nests were found in shrubbery near native grassland area. Two other birds were flushed from brush in the area, but no other nests were found. Probably a few cuckoos nest in the area each year. Cuckoos were especially common in 1973 when there was an extra large supply of caterpillars.

Shorteared Owl: No nests were found, but, in two locations (native grassland area and Rainbow Bridge) birds were flushed from the same spots throughout the summer. Presumably nest in the area most years: one nest found in June, 1974, in a field north of Regina University.

Yellow-shafted Flicker: Fairly common. $7 n, 24 \mathrm{e}$ (in three nests, the other four were too high to get at.) Estimated 6 or 7 pairs nest in the area each year.

Eastern Phoebe: Rare, probably fairly regular. $1 \mathrm{n}, 5 \mathrm{e}$. One nest was found under an abandoned bridge east of the Rainbow Bridge. Two other nests were found half a mile beyond the area, to the east. Probably present every year. (One nest found in the same location in 1973, and one nest found in an old shed near bypass in June, 1974.)

Eastern Kingbird: Common. $11 \mathrm{n}, 42 \mathrm{e}$. Of our two species of fearless kingbirds, the Eastern is slightly more common. Common throughout the area, particularly in shrubbery near native grassland area. One nest contained an unusual number of 9 eggs. In 1974, kingbirds were especially common (35 nests found in the area). Probably around 15 pairs nest each year.

Western Kingbird: Common. 9n, 30e. Also favors shrubbery around the native grassland area. The Western was also especially common in 1974 (30 nests found in area). Probably about a dozen nest in the area each year. (One nest found in 1974 contained 8 eggs.)

Least Flycatcher: Fairly common. 4n, $12 \mathrm{e},(3 \mathrm{n})$. Probably more than half a dozen nest in the area each year. Favours the shrubbery around native grassland area. The Least Flycatcher nests between mid-June and August. One nest was too high to reach. (In 1972, 2 nests were found, in 1973, 3 nests were found, in 1974, 4 nests were found. 


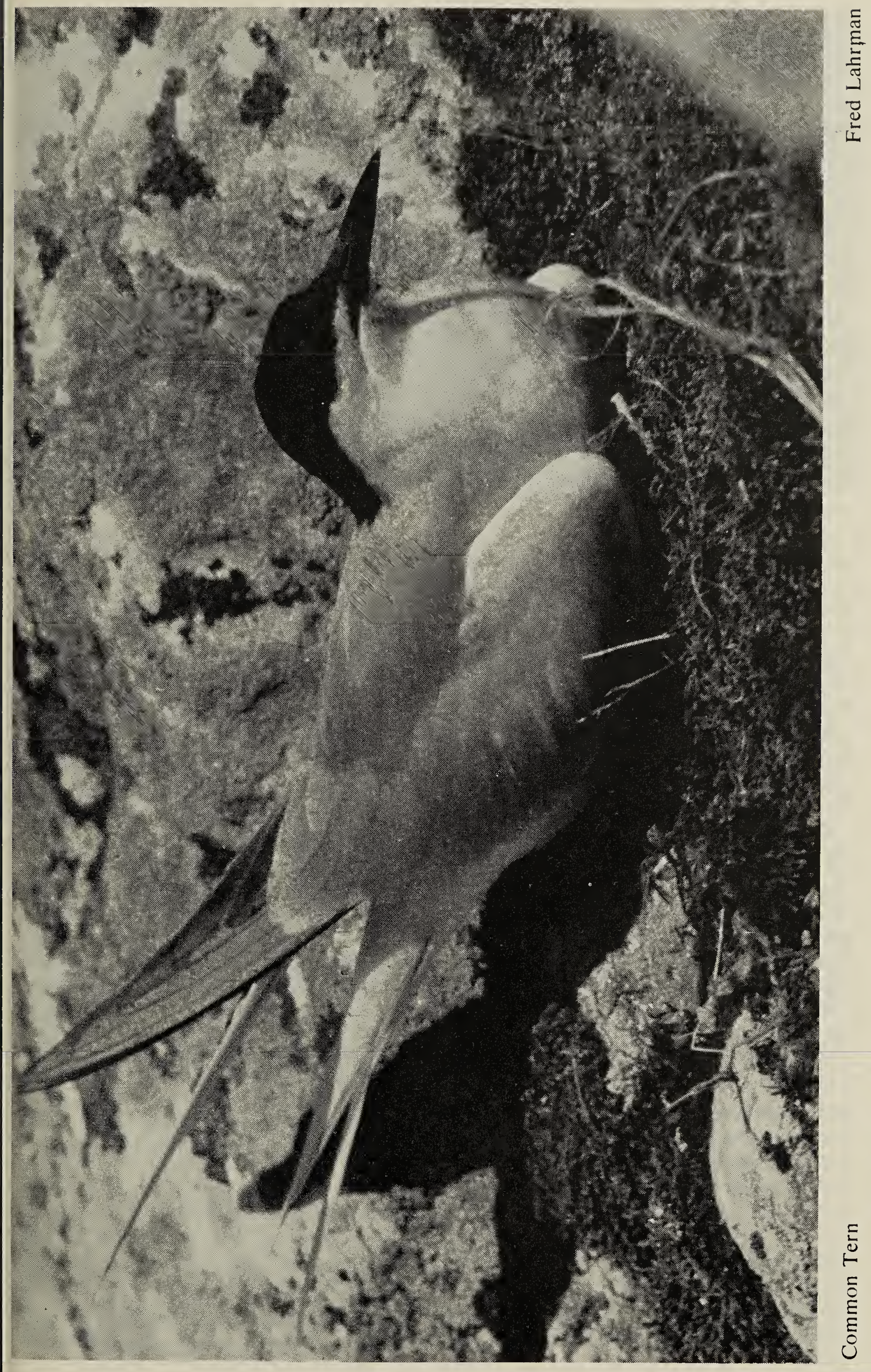




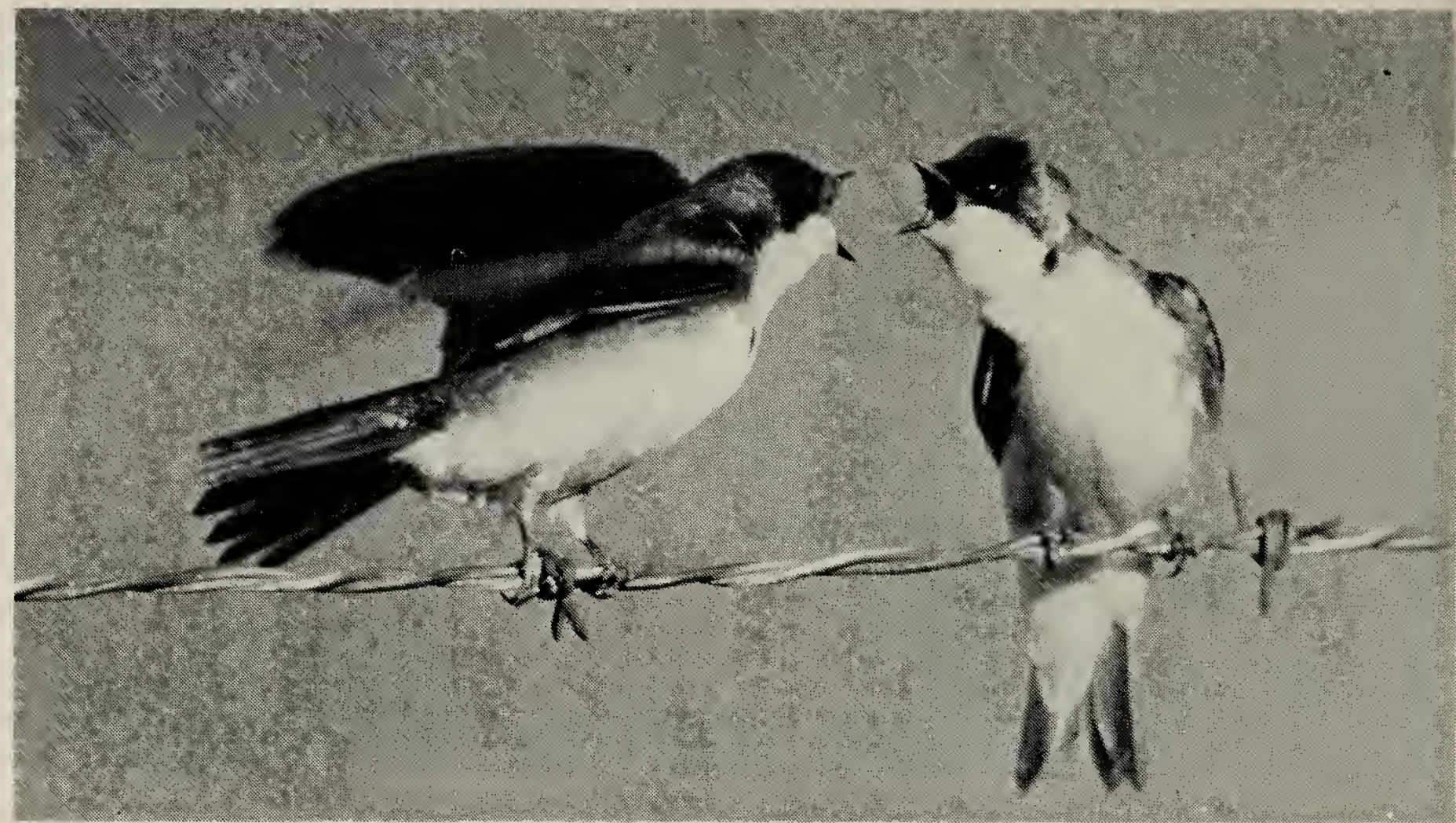

Tree Swallow

Fred Lahrman

Horned Lark: Fairly Common. 2n, 6e, $3 y$. One nest was found near the native grassland area and one near the Plains Hospital. Three other birds were flushed from the field east of Rainbow Bridge, but no other nests were found.

Tree Swallow: Fairly common. $7 \mathrm{n}, 45 \mathrm{e}$. All nests were found in nest boxes on Goose and Tern Islands and the native grassland area. Two other pairs of birds were seen at Flicker holes, but were too high to reach. One of the nest boxes, set out for swallows, contained a House Sparrow nest and another contained a House Wren nest.

Bank Swallow: Fairly common. $11 \mathrm{n}, 2 \mathrm{y}$. They have previously nested in the bank along Wascana Lake, east of the Regina Power Plant. The swallows this year nested in two small colonies of 5 and 6 pairs near the Wascana Country Club.

Barn Swallow: Fairly common. 8n, 37e. They nest in suitable locations throughout the area. One pair of Barn Swallows have been nesting on top of a door light at the Waterfowl Park Office for 4 years.

Cliff Swallow: Uncommon. 2n, 9e. Both nests were found under an abandoned bridge east of Rainbow Bridge. Three other nests were found outside of the area to the east.
Purple Martin: Fairly common at the martin houses. 9n. According to Lorne Scott, the Museum's three martin houses contained 9 pairs. These are the only martin houses in the Waterfowl Park area. On evenings in late August and early September, Keith Neufeld and myself watched from the Display Ponds a flock of over 1000 martins and swallows swarm over the lake hawking mosquitoes. By 9:00-9:30, each night the barbed-wire fences and power lines at the park would be completely covered by martins, Tree, Bank, Barn and Cliff Swallows and the odd Eastern and Western Kingbird.

Common Crow: Common. 12n, 56e. Nests were found throughout the area. Most people think the crow is a threat to songbirds. This is only true if the population is too high. Regina has a good population of crows and as long as they do not become too common, they should not be destroyed. Ten to 15 pairs nest in the area each year.

House Wren: Fairly common. 5n, $31 \mathrm{e}$. Two nests were found in natural cavities. One nest was found in a Tree Swallow's house. One pair of birds built 5 nests in wren houses, 14 feet apart, near the Waterfowl Park Office. Only one box contained eggs. 
Yellow Warbler: Common. 5n, 13e, 8y. Seemed to favor shrubbery near native grassland. Nests were between 4 and 5 feet off the ground. Probably over a dozen birds nest in the area each year. A cowbird egg was found in 2 nests.

Northern Waterthrush: At the base of the spillway at the Regina Power Plant on August 4, Keith Neufeld and I observed a waterthrush running nervously on top of the spillway. The next day, I saw the bird again and I thought I would take a closer look beneath the spillway. There, sitting on the walkway below, were four young birds which I believed to be young waterthrushes. In a few seconds, they took off with the adult bird and flew a short distance into the cattails. I estimated the young had been out of the nest for 2 or 3 days. This will have to remain a hypothetical record because only one observer had seen the young and because there are no other breeding records in the Regina area.

Common Yellowthroat: Fairly common. $1 \mathrm{n}, 5 \mathrm{e}$. An estimated 6 or 7 pairs of yellowthroat nest in the area each year. On June 16, Lorne Scott and Fred Lahrman found a yellowthroat nest in the cattails on the southeast side of Rainbow Bridge.

Bobolink: Uncommon and irregular. $2 y$. No nests were found but apparently 5 pairs were definitely on territory in the field on the northwest side of Rainbow Bridge. Females were flushed by rope dragging many times but, unfortunately, no nests were found. Two other pairs were also on territory in the native grassland area but no nests were found there. In mid-August one young, of one family, was found about 2 days out of the nest. It could barely fly well enough to escape. One additional young was seen at Rainbow Bridge.

Western Meadowlake: Common. 3n, 5e, $7 \mathrm{y}$. One family of young recently out of nest was observed in early June at the Centre of the Arts. Females were often flushed but no other nests were found.

Yellow-headed Blackbird: Very common. 67n, 215e, 25y. Present wherever there are cattails and willows. They are more colonial than redwings. They favor Tern Island, bypass and Rainbow Bridge areas. The first young were hatched in early June. Sixteen nests each contained one cowbird egg. Three contained 2 cowbird eggs each Lorne Scott banded 40 young this summer. The young were fledged by June 17 . Not as many were nesting as in the previous 2 years.

Red-winged Blackbird: Very common. $43 \mathrm{n}, 126 \mathrm{e}, 31 \mathrm{y}$. Common in cattails and willows throughout the area. Usually slightly more common than yellowheads. Eleven nests containing one cowbird and 2 nests containing 2 cowbird eggs were found.

Northern (Baltimore) Oriole: Fairly Common. 3n, 1e, 9y. Two nests were too high to reach. One nest contained one egg and 2 young. Two other groups of young were seen out of the nest. One group was sitting by the nest. Each group contained 4 young. The nests were between 15 and 40 feet up in the trees.

Brewer's Blackbird: Fairly common. 3n. $14 \mathrm{e}, 2 \mathrm{y}$. Two nests were found in native grassland area in the rose bushes. The other nest was in the Wascana Nursery, 3 feet up in a spruce tree in a colony of grackles. Probably about 8 or 9 pairs nest in the area each year.

Common Grackle: Common. 16n, 75e $9 y$. Five nests were found in the Wascana Nursery. Three were found ir shrubbery near the native grassland The other nests were scatterec throughout the area. Two nests wer found in cattails and one was found in a rose bush on the north side of Goose Island. Young were out of the nests a early as June 7 , when 9 young wer seen. Probably around 15 pairs nest ir the area each year.

Brown-headed Cowbird: Commor throughout area. One Least Flycat cher, one Cedar Waxwing, one American Goldfinch, 2 Yellow War bler, 16 Yellow-headed Blackbird anc 11 Red-winged Blackbird nests, each contained one cowbird egg. On cowbird egg was also found in a cat bird nest and one in a robin's nest 


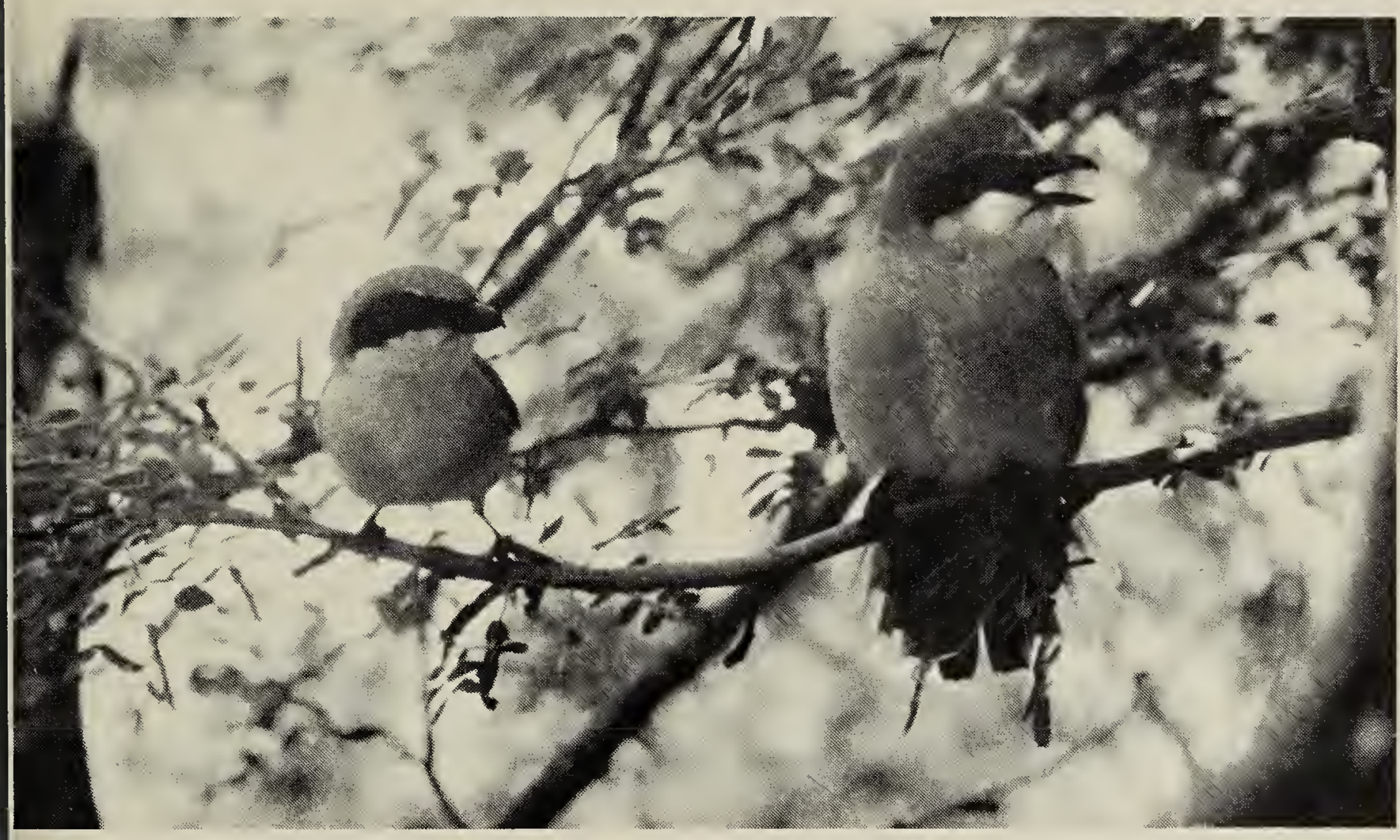

Loggerhead Shrikes.

Gary Anweiler

both eggs were thrown out by the adult birds. Two Yellow-headed Blackbird and 2 Red-winged Blackbird nests each contained 2 cowbird eggs.

American Goldfinch: Fairly common. $5 \mathrm{n}, 9 \mathrm{e}$. (Two nests were too high to reach.) Nests were found between 4 and 15 feet up in the trees. One nest was destroyed by intruders. Nests were found in the Wascana Nursery and the shrubbery near the native grassland area. Probably between 4 and 9 pairs nest each year. (1972 - 2 nests were found, $1973-5$ nests were found, 1974 - 9 nests were found.)

Savannah Sparrow: Uncommon in uitable habitat. $1 \mathrm{n}, 5 \mathrm{e}$. One nest was found in the native grassland, one pair was found on the territory near the Regina Power Plant and a pair was een in a field near Rainbow Bridge. Probably about 4 or 5 pairs nest each vear.

Vesper Sparrow: Fairly common in uitable habitat. $2 \mathrm{n}, 9 \mathrm{e}$. One nest was found in the native grassland area; the other nest was found on Goose Island, poth in mid-June. Two other pairs vere on territory on Goose Island, and bne pair was on territory near the Regina Power Plant. Probably 9 or 10 pairs nest in the area each year.
Chipping Sparrow: Uncommon in suitable habitat. $1 \mathrm{n}, 2 \mathrm{e}, 5 \mathrm{y}$. One nest was found near the Regina Power Plant with young about 10 days old. (Nest also contained 2 unhatched eggs.) Two other pairs were found on territory in native grassland. Usually only a few pair nest in the area each year.

Clay-colored Sparrow: Fairly common in suitable habitat. One nest was found in the native grassland by Fred Bard in mid-June, the other nest was found at the Regina Power Plant. One bird was flushed on Goose Island but no nest was found. Three pairs were on territory in the native grassland area.

Song Sparrow: Fairly common in suitable habitat. In, 5e. One nest was found on Goose Island in mid-June. The nest was later destroyed by a rainstorm on June 25. One other pair was on territory on Goose Island, Regina Power Plant, and 3 pairs were on territory in the native grassland area.

Summary of the Nesting Survey: A total of 67 species bred in the area in 1975 in addition to 8 hypothetical species. A total of 613 nests was found and 2,829 eggs. Over 100 species of birds have bred in the Regina area. So far, about 
one-third of the total population of Saskatchewan birds and four-fifths of Regina's breeding bird population breed have bred in the Regina Waterfowl Park.

Acknowledgements: Thanks go to Vic Wadman, at the Regina Weather Office, for his much needed help in supplying the monthly weather summaries for the report of the nesting survey.

To Dwayne Harty and Keith Neufeld, who spent much of their time throughout May, June and July, helping me search the area for nesting species.

I am very grateful to Fred Lahrman and Lorne Scott, who gave suggestions on planning the survey and supplied the photographs.

I am very thankful to Margaret Belcher and Lorne Scott for proof- reading and editing the nesting survey report.

Most of all, I am especially indebted to Fred Bard, who introduced me to the Regina Waterfowl Park in 1972, and who originally suggested my doing a nesting survey. Throughout the past 5 years, $\mathrm{Mr}$. Bard has given continued encouragement and help to me in my interest in birds.

Editor's Note: Robyn Donison is 14 years old. Richard Sanderson's 1962 study involved only 45 hours of field work with Bill Fleming. Significant differences in some populations are apparent, e.g., the earlier study turned up 14 Pied-billed Grebe nests, 117 Coot nests and 12 Common Tern nests. Only 14 species were listed for 1962.

\section{ADDITIONAL MANITOBA RECORDS OF SHORT-TAILED SHREW}

\author{
WALTER KRIVDA, \\ Box 864, The Pas, Manitoba
}

Apparently the Short-tailed Shrew, Blarina brevicauda manitobensis Anders., is less scarce than is generally thought. I first collected this subspecies near The Pas, Manitoba, in 1951. My note in the Canadian FieldNaturalist (1951) gives the circumstances and data of the first specimen collected this far north in Manitoba.

In September, 1973, Mr. Phil Reader of Reader's Lake, 13 miles from The Pas, took a Short-tailed Shrew in a mouse trap. The specimen, in alcohol, is in the writer's collection. This specimen was taken near a house and out-buildings in a stand of jack pines in sandy woodland.

In February, 1975, the third local specimen for this area was found frozen to death in the writer's wood pile in town. This specimen was somewhat desiccated when found. It was put into alcohol and donated to the Manitoba Museum of Man and Nature, Winnipeg. When being made into a museum skin, the fur slipped from one hind quarter. The skull is in perfect condition.

As is so often the case with a new range extension, once the proper microhabitat has been discovered, it may prove to be more frequent than these few records over a 25-year period would indicate. 